\title{
Book review: Planetary Gentrification
}

\author{
Anne-Cécile Mermet \\ Équipe Interdisciplinaire de Recherche sur le Tourisme, \\ Université Paris 1 Panthéon-Sorbonne, Paris, 75005, France \\ Correspondence to: Anne-Cécile Mermet \\ (anne-cecile.mermet@ens-lyon.org) \\ Published: 1 December 2017
}

Lees, L., Shin, H. B., and López-Morales, E.: Planetary Gentrification, John Wiley \& Sons, Cambridge, Malden, 248 pp., ISBN-13: 978-0-7456-7165-9, EUR 20.90, 2016.

Planetary Gentrification brings together the conclusions of a wide, ambitious and timely research program on global gentrification led by an international team of prominent scholars in urban studies (Loretta Lees, Hyun Bang Shin and Ernesto López-Morales) who have long investigated gentrification in, respectively, Anglo-American, Asian and Latin American cities. The release of this book closely follows the publication of Global Gentrifications, a collection of case studies on gentrification beyond Western cities and two special issues on "Gentrification in the Global East" (Urban Studies, 2016, Vol. 53, Issue 3, Shin et al., 2016) and on "Latin American Gentrification" (Urban Geography, 2016, Vol. 37, Issue 8, López-Morales et al., 2016) edited by the same authors. The book therefore offers an inspiring and up-to-date synthesis of the main advances on the issue of global gentrification.

The authors follow on from the research agenda initiated by Neil Smith's late work on "gentrification generalized" (Smith, 2002, 2006), who suggested that gentrification is henceforth generalized to every space and every economic sector integrated to contemporary capitalism. The issue of "global gentrification" has indeed been at the forefront of the gentrification literature over the past 15 years, with a series of books aiming at identifying cases of gentrification outside its original geographical context (Atkinson and Bridge, 2005; Porter and Shaw, 2009). It has recently been the subject of heated debate, through a range of publications, contesting the relevance and legitimacy of applying a concept that has been coined by Western scholars for Western cities to nonWestern contexts (Ghertner, 2014; Maloutas, 2012). Here, the authors are taking the opposing view of the debate, by defending the soundness of the inputs provided by the gentrification theory to give an account of the contemporary sociospatial restructuring of non-Western cities. They "advance the view that gentrification is becoming increasingly influential and unfolds at a planetary scale" (p. 4) while strongly rejecting the diffusionist thesis according to which gentrification would have linearly spread from the Global North to the Global South. This book aims to build gentrification as a central concept in "truly global urban studies" (p. 12) which would stop analysing Global North and Global South cities through different theoretical frameworks.

Drawing on the most recent theoretical developments in urban studies, the theoretical framework of the book presented in the introduction combines Jennifer Robinson's "comparative urbanism" with Neil Brenner and Christian Schmid's theory on "planetary urbanization" to bridge the gap between urban and post-colonial studies, "unpack gentrification" and set it as a central concept in urban theory. Rather than a simple comparison of "similarity and difference among cities", the authors defend a "relational comparative approach" (p. 13) which puts the emphasis on the transnational and interconnected features of contemporary urban processes. They especially argue that, whether in southern or northern cities, local governments increasingly use the secondary circuit of capital (i.e. real estate) as a capital accumulation strategy, resulting in increasing inequalities and, above all, variegated forms of displacement. Chapter 2 (New Urbanizations) sets the book within the context of the history of gentrification studies by providing a persuasive genealogy of the concept. It shows that gentrification has progressively freed itself from all the contextual factors that lay at the heart of early studies on the topic. Initially tightly bound to a specific location (inner-city neighbourhoods) and to a specific urban process (rehabilitation), the concept has indeed been refashioned to include newly built urban projects 
as well as rural or suburban areas, provided that these urban restructurings involve the displacement of existing users by economically more powerful stakeholders. Gentrification is henceforth above all understood as a displacement process triggered by the increasing and variegated dynamics of capital reinvestment in the built environment worldwide.

The gentrification theory has long been structured by two ranges of causality inherited from the "production vs. consumption" debate from the 1980s and 1990s. The two following chapters apply this well-established framework to gentrification in non-Western contexts. Through an international literature review on gentrification in cities just as various as Prague, Seoul or Santiago, the authors demonstrate that the main economic drivers of gentrification (creative destruction of the built environment, urban entrepreneurialism, urban projects enhancing the "spatial capital" of certain locations to attract upper-income social groups, post-crisis contexts providing significant reinvestment opportunities) remain powerful explanatory tools to give an account of dispossession processes in Global South cities. Drawing on Slater's paper on planetary rent gap (Slater, 2017), they especially point out that the rent gap theory is still extremely relevant to understand how significant urban projects launched in southern cities actually conceal the capture of capitalized ground rent by economically powerful (and often transnational) developers. Maybe most importantly, they highlight the crucial role of the state in the process, by enabling and facilitating such capital reinvestment. They therefore conclude that stateled gentrification theory is more relevant than ever when it comes to non-Western contexts. Chapter 4 (Class, Capital, State) focuses on the "consumption side" of global gentrification, by questioning the relevance of the notion of "global middle class" which would fuel a global gentrifying demand, as the considerable growth of middle class in emerging countries would suggest. It scrutinizes the diversity of political behaviours and lifestyle of these middle classes. For example, it reviews numerous case studies to highlight the fact that, in contrast to early gentrification processes in North American cities, gentrification in southern cities is more likely to be fuelled by a rejection of the suburban lifestyle by middle class households. Even dynamics such as historic preservation do not come from pioneer gentrifiers anymore but are increasingly driven by the state to maximize the land rent. The authors therefore conclude that the diversity of middle classes across the globe makes it impossible to group them in a consistent "global middle class" category, and that, whatever it be, "planetary gentrification is produced less by global gentrifiers [...] and more by (trans)national developers, financial capital and transnational institutions" (p. 110).

The fifth chapter (A Global Gentrification Blueprint?) tackles the question of a hypothetic diffusion of gentrification from north to south and west to east by analysing the circulation of several famous urban models (the Bilbao and Barcelona models, Florida's creative city, etc.) which, behind labels such as "urban regeneration" or "urban renewal", actu- ally bring about gentrification and displacement. While this chapter provides a very interesting insight on the transnational circulations of such models, it is not totally convincing in reassessing the diffusionist theory of gentrification since most of the examples used in the chapter have actually been shaped in northern cities and spread worldwide afterwards.

Chapters 6 and 7 focus on forms of gentrification that are more specific (although not limited) to southern cities. Chapter 6 (Slum Gentrification) aims to demonstrate that the gentrification theory can shed some new light on current slum redevelopment programs all over the world. The authors detail three case studies (Mumbai, mainland China's slums and the reinvestment of the favelas in Rio related to the Olympic games) by focusing on the displacement of the inhabitants of slums resulting from these urban policies as well as on the forms of grass-root contestations and resistance defending the "right to stay put". Chapter 7 (Mega-Gentrification and Displacement) analyses the extent to which the mega urban projects that are multiplying from Abu Dhabi to Chinese cities produce displacement on an unprecedented scale.

This book offers a serious attempt to build a robust urban theory which would be able to encompass the different forms of urban restructuring beyond their contextual specificities. It provides a much-needed synthesis which compares and puts into perspective the conclusions of a wide array of recent case studies on global gentrification. Nevertheless, even if the book explicitly takes a strong stance defending the "universal" nature of gentrification, it does not address directly the critiques expressed by scholars such as Maloutas or Ghertner who contest the possibility of applying the gentrification theory outside its original context. The key issue here lies in the definition given to gentrification and especially in the fact that gentrification is still a "chaotic concept" which maintains an increasingly intimate but also intricate relation with the "displacement" question. Is it to say that gentrification amounts to displacement? Does "displacement beyond gentrification", to quote Ghertner, exist? What are the specificities of "gentrification-led" displacement and which criteria should one fulfil to be able to label an urban change involving displacement "gentrification"? The book often overlooks these crucial questions and only suggests the possibilities of "non-gentrification-led" forms of displacement in the penultimate chapter, in which the authors introduce a stimulating distinction between "development-led displacement" and the process of gentrification (p. 174) which deserved more detailed development. Tackling this issue in more detail from the beginning would have made some stances and examples presented throughout the book more convincing and would have prevented the reader from wondering whether every neighbourhood change would eventually fall in the scope of gentrification. All these questions are still open today, as illustrated by the recent debate in the journal City initiated by this wide project on global gentrification (Bernt, 2016; Ghertner, 2015; López-Morales, 2015). All of this aside, the book provides a major contribution to the field of gentrifi- 
cation and will be of considerable interest for urban studies scholars, students and urban activists and will be a highly valuable tool to fuel further research on transnational gentrification.

\section{References}

Atkinson, R. and Bridge, G.: Gentrification in a Global Context: The New Urban Colonialism, Routledge, London, 2005.

Bernt, M.: Very particular, or rather universal? Gentrification through the lenses of Ghertner and López-Morales, City, 20, 637-644, https://doi.org/10.1080/13604813.2016.1143682, 2016.

Ghertner, D. A.: India's Urban Revolution: Geographies of Displacement beyond Gentrification, Environ. Plan. A, 46, 15541571, https://doi.org/10.1068/a46288, 2014.

Ghertner, D. A.: Why gentrification theory fails in "much of the world", City, 19, 552-563, https://doi.org/10.1080/13604813.2015.1051745, 2015.

López-Morales, E.: Gentrification in the global South, City, 19, 564-573, https://doi.org/10.1080/13604813.2015.1051746, 2015.
López-Morales, E., Shin, H. B., and Lees, L. (Eds.): Latin American gentrifications, Urban Geography, 37, 1091-1252, http://www. tandfonline.com/toc/rurb20/37/8, 2016.

Maloutas, T.: Contextual Diversity in Gentrification Research, Crit. Sociol., 38, 33-48, https://doi.org/10.1177/0896920510380950, 2012.

Porter, L. and Shaw, K. (Eds.): Whose urban renaissance?: An international comparison of urban regeneration strategies, Routledge, London, 2009.

Shin, H. B., Lees, L., and López-Morales, E. (Eds.): Locating gentrification in the Global East, Urban Studies, 53, 455-625, http://journals.sagepub.com/toc/usja/53/3, 2016.

Slater, T.: Planetary Rent Gaps, Antipode, 49, 114-137, https://doi.org/10.1111/anti.12185, 2017.

Smith, N.: New Globalism, New Urbanism: Gentrification as Global Urban Strategy, Antipode, 34, 427-450, https://doi.org/10.1111/1467-8330.00249, 2002.

Smith, N.: Gentrification Generalized: From Local Anomaly to Urban "Regeneration" as Global Urban Strategy, in: Frontiers of Capital: Ethnographic Reflections on the New Economy, edited by: Downey, G., 191-208, Duke University Press Books, Durham and London, 2006. 